\title{
APPARENT DIGESTIBILITY OF SELECTED FEED INGREDIENTS IN DIETS FOR MUD CRAB (Scylla paramamosain)
}

\author{
Ketut Suwirya*), Nyoman Adiasmara Giri ${ }^{*}$, M. Marzuqi*), and Sophia Sagala*)
}

\begin{abstract}
Cultured mud crabs (Scylla spp.) are commonly fed with 'trash' fish. Insufficient supply, high cost and variable quality of 'trash' fish has lead to a need to develop costeffective and environmentally friendly formulated diets. This study was conducted to determine quality of selected feed ingredients as protein sources in mud crab diets based on their nutrient composition and digestibility coefficients for dry matter (ADMD), crude protein, lipid and energy. The digestibility coefficients for ADMD ranged from $82.46 \%$ to $89.20 \%$ Animal- based feedstuffs such as shrimp head, tiny shrimp and squid liver meal had higher ADMD values than fish meal. Of the plant- based feedstuffs, soy bean meal had the highest ADMD values $(89.20 \%$ and corn gluten had the lowest $(82.46 \%$. Corn gluten had the lowest protein digestibility $(78.81 \%$ and soy bean meal had the highest $(96.05 \%$. The lowest energy digestibility $(71.13 \%)$ was obtained in corn gluten meal. Soy bean meal had a higher energy digestibility value $(98.48 \%$ ) than fish meal $(85.95 \%$. All animal meal sources had similar energy digestibility values $(85.86 \%-92.09 \%)$.
\end{abstract}

\section{KEYWORDS: digestibility, feed ingredient, mud crab}

\section{INTRODUCTION}

Mud crab has good potential for commercial culture. Cultured mud crabs are commonly fed with 'trash' fish. However, due to the insufficient supply, variable cost and quality of 'trash' fish, there is a need to develop costeffective and environmentally friendly formulated diets. Cost effective feed can be produced through the formulation of inexpensive feed ingredients and inclusion of ingredients with high digestibility which is beneficial for the environment. Some potential ingredients available for formulated crab diets are: fish, squid liver, tiny shrimp, shrimp head, corn gluten, and soy bean meal. Effective incorporation of an ingredient, however, requires information on its digestibility by the target species.

A feed ingredient may appear from its chemical composition to be an excellent source of nutrients but may have little actual value unless it can be digested and absorbed by the target species. Consequently, knowledge of nutrient digestibility of various feed ingredients used in formulating diets for the target species is important. Lee \&Lawrence (1997) recommended the use of chromic oxide $\left(\mathrm{Cr}_{2} \mathrm{O}_{3}\right)$ as an inert indicator to measure digestibility of feed ingredients for crustaceans and many researchers have reported the apparent digestibility of dry matter, protein, lipid, carbohydrate using $\mathrm{Cr}_{2} \mathrm{O}_{3}$ (Forster \& Gabbott, 1971; Fennuci et al., 1982; Akiyama et al., 1989; Tuan et al., 2006; Catacutan et al., 2003).

Digestibility studies of some ingredients by Scylla serrata have been reported by Tuan et al. (2006) and Catacutan et al. (2003). These results indicated that S.serrata can efficiently utilize certain feed ingredients. Apparent dry matter digestibility of both studies was $85.2 \%$ 93.6\%(Catacutan et al., 2003) and 70.0\%-95.7\% (Tuan et al., 2006). This information is not yet

*) Research Institute for Mariculture, Gondol, Bali, Indonesia 
available for Scylla paramamosain. This study was conducted to determine the suitability of selected feed ingredients as protein sources for S. paramamosain diets based on their nutrient composition and the digestibility coefficients for dry matter, crude protein, lipid and energy.

\section{MATERIAL AND METHODS}

A total of 48 mud crabs (mean body weight $120.5 \pm 7.1 \mathrm{gram}$ ) were used to test the suitability of the following test ingredients for inclusion in mud crab diets: local fish meal, shrimp head meal, tiny shrimp meal, squid liver meal, corn gluten meal, defatted soybean meal, and feather meal.

The methods of Cho et al. (1982) and Forster (1999) were adapted for this study and used a ratio of 70:30 of the reference diet to test ingredient (Table 1 ). The reference diet was formulated to meet known nutrient requirements of mud crabs. All experimental diets contained $1 \% \mathrm{Cr}_{2} \mathrm{O}_{3}$ as an external indicator and $2 \%$ carboxymethylcellulose (CMC) as a binder. The mud crabs were acclimated with a reference diet (without $\mathrm{Cr}_{2} \mathrm{O}_{3}$ ) for 2 weeks after which they were fed experimental diets twice daily $(08.00 \mathrm{~h}$ and $15.00 \mathrm{~h}$ ) at a rate of $5 \%$ body weight per day. After acclimation, all mud crabs were assigned to the experimental diets groups. Six crabs were included for each group with triplicates. Faeces were pooled from crabs in each replication until enough was obtained for analysis. All samples were stored in a refrigerator until required for analysis. The feeds and faeces were analyzed for proximate analysis using standard methods (AOAC, 1990) and for $\mathrm{Cr}_{2} \mathrm{O}_{3}$ (Furukawa \& Tsukahara, 1966).

Apparent digestibility coefficients (ADCs) of dry matter, protein, energy and lipid were then measured using the methods of Cho et al. (1982) and Forster (1999) with chromic oxide as the inert marker. Apparent digestibility coefficients (ADCs) of each nutrient were calculated from the equation:

$$
A D C=100-(100 \times \mathrm{Md} / \mathrm{Mf} \times \mathrm{Nf} / \mathrm{Nd}),
$$

Where $\mathrm{M}$ and $\mathrm{N}$ are the percentage of marker and nutrient, respectively, and $d$ and $f$ are diet and faeces, respectively. When ingredients are partially substituted into the reference diet to give a combined diet, the equation for any given nutrient becomes:

Table 1. The composition of reference and test diets for in vivo digestibility experiments on various feed ingredients (g/ $100 \mathrm{~g}$ feed)

\begin{tabular}{lcc}
\hline \multicolumn{1}{c}{ Ingredients } & $\begin{array}{c}\text { Reference } \\
\text { diet (\%) }\end{array}$ & $\begin{array}{c}\text { Test } \\
\text { diet (\%) }\end{array}$ \\
\hline Fish meal & 44.1 & 30.5 \\
Head shrimp meal & 10.0 & 6.9 \\
Squid liver meal & 5.0 & 3.5 \\
Defatted soybean meal & 10.0 & 6.9 \\
Casein & 6.0 & 4.1 \\
Wheat flour meal & 5.5 & 3.8 \\
Soybean oil & 2.5 & 1.7 \\
Fish oil & 1.2 & 0.8 \\
Lecithin & 2.0 & 1.4 \\
Min Mix & 2.0 & 1.4 \\
Vit Mix & 2.5 & 1.7 \\
Dextrin & 6.2 & 4.3 \\
$\mathrm{CMC} \mathrm{C}_{2} \mathrm{O}_{3}$ & 2.0 & 2.0 \\
Test ingredients & 1.0 & 1.0 \\
\hline & - & 30.0 \\
\hline
\end{tabular}


$A D C=[(a+b) \times A D C c o m-(a) \times$ ADCref $] b^{-1}$

Which takes into account the different nutrient composition of the reference diet and test ingredient, where $a=$ level of nutrient in reference diet $x$ (100 - level of test ingredient in combined diet), and $b=$ level of nutrient in test ingredient $x$ level of test ingredient in combined diet.

All data were analyzed by one- way ANOVA and differences between means treatment were considered significant at $\mathrm{P}<0.05$ (Steell \&Torrie, 1960).

\section{RESULTS}

The proximate composition $(\mathrm{g} / 100 \mathrm{~g}$ dry weight) of various feed ingredients is shown in Table 2. Protein levels in fish meal and other feedstuffs of animal origin used in this experiment were generally high $(34.69 \%$ $86.30 \%$. Protein content of feed ingredients from plant sources ranged from $54.13 \%$ to $60.89 \%$ Likewise, the levels of ash in fish meal and shrimp head meal were higher $(19.38 \%$ $33.42 \%$ than those in feed ingredients of plant origin $(1.29 \%-6.92 \%$. The level of fiber in fish meal was lower than that of other ingredients tested. Squid liver meal had the highest lipid content $(17.76 \%$ ).

Table 3 shows the apparent digestibility coefficients (ADCs) for dry matter (ADMD), protein, lipid, and energy. The digestibility coefficients for ADMD ranged from $82.46 \%$ to $89.20 \%$ Of the feedstuffs of animal origin head shrimp, tiny shrimp and squid liver meal had higher ADMD values than fish meal. Soy bean

Table 2. Proximate composition of various ingredients for in vivo digestibility experiment (g/100 dry weight)

\begin{tabular}{lcrlrr}
\hline \multicolumn{1}{c}{ Ingredients } & Protein & Lipid & Fiber & NFE1 & Ash \\
\hline Fish meal & 64.36 & 7.61 & 1.85 & 6.80 & 19.38 \\
Shrimp head meal & 34.69 & 4.47 & 5.61 & 21.81 & 33.42 \\
Tiny shrimp meal & 59.97 & 4.23 & 4.80 & 5.85 & 25.15 \\
Squid liver meal & 46.60 & 17.76 & 2.30 & 25.73 & 7.61 \\
Poultry feather meal & 86.30 & 6.71 & 2.51 & 1.71 & 2.77 \\
Corn gluten meal & 60.89 & 15.22 & 3.36 & 19.24 & 1.29 \\
Soy bean meal (defatted) & 54.13 & 3.31 & 3.62 & 32.02 & 6.92 \\
\hline
\end{tabular}

1 Nitrogen free extract $=100-$ (\%crude protein $+\%$ crude lipid $+\%$ crude fiber + \%ash)

Table 3. Digestibility of some feed ingredients on mud crab

\begin{tabular}{lcccc}
\hline \multicolumn{1}{c}{ Ingredients } & $\begin{array}{c}\text { Dry matter } \\
\text { digestibility* } \\
(\%)\end{array}$ & $\begin{array}{c}\text { Protein } \\
\text { digestibility* } \\
(\mathbf{\%})\end{array}$ & $\begin{array}{c}\text { Lipid } \\
\text { digestibility* } \\
(\mathbf{\%})\end{array}$ & $\begin{array}{c}\text { Energy } \\
\text { digestibility* } \\
\mathbf{( \% )}\end{array}$ \\
\hline Local fish meal & $84.25^{\mathrm{b}}$ & $86.12^{\mathrm{b}}$ & $57.62^{\mathrm{abc}}$ & $85.95^{\mathrm{b}}$ \\
Head shrimp meal & $85.74^{\mathrm{d}}$ & $88,05^{\mathrm{bc}}$ & $71.25^{\mathrm{bc}}$ & $85.86^{\mathrm{b}}$ \\
Tiny shrimp meal & $85.32^{\mathrm{c}}$ & $90.66^{\mathrm{c}}$ & $34.33^{\mathrm{a}}$ & $93.01^{\mathrm{bc}}$ \\
Squid liver meal & $87.15^{\mathrm{c}}$ & $90.02^{\mathrm{bc}}$ & $89.14^{\mathrm{c}}$ & $91.36^{\mathrm{bc}}$ \\
Corn gluten & $82.46^{\mathrm{a}}$ & $78.81^{\mathrm{a}}$ & $51.37^{\mathrm{ab}}$ & $71.13^{\mathrm{a}}$ \\
Soy bean meal & $89.20^{\mathrm{f}}$ & $96.05^{\mathrm{d}}$ & $43.25^{\mathrm{a}}$ & $98.48^{\mathrm{c}}$ \\
Poultry feather meal & $87.19^{\mathrm{e}}$ & $95.14^{\mathrm{d}}$ & $23.50^{\mathrm{a}}$ & $92.09^{\mathrm{bc}}$ \\
\hline
\end{tabular}

* Values in the same column followed with similar superscript are not significantly different $(P>0.05)$ 
meal had the highest ADMD value and corn gluten was the lowest.

Analysis of variance (Table 3 ) showed that protein, lipid and energy digestibility values of some ingredients were significantly different from one another $(\mathrm{P}<0.05)$. Corn gluten had the lowest protein digestibility value while soy bean meal had the highest $(P<0.05)$. Protein digestibility values of local fish, head shrimp, and squid liver meal were not significantly different from one another $(P>0.05)$.

Lipid digestibility values of squid liver and head shrimp meal were higher than soy bean meal $(P<0.05)$. Lipid digestibility values of local fish, head shrimp, and corn gluten meal were not significantly different from one another $(P>0.05)$.

Energy digestibility values of all ingredients were relatively high $(71.13 \%-98.48 \%)$. The lowest energy digestibility value was obtained with corn gluten meal. Soy bean meal had a higher energy digestibility value than fish meal. All animal meal sources had similar energy digestibility values (Table 3 ).

\section{DISCUSSION}

Protein quality of dietary ingredients is generally a leading factor affecting mud crab performance, and protein digestibility is the first measure of its availability by mud crab. Protein quality of dietary protein sources depends on the composition of amino acids and their digestibility. Deficiency of an essential amino acid leads to poor utilization of dietary protein and consequently reduces growth and decreases feed efficiency (Halver $\&$ Hardy, 2002). The present study showed that ADCs of dry matter, protein, lipid, and energy in the test ingredients for mud crab, S. paramamosain were affected by test ingredients $(P<0.05)$. The differences in ADCs of nutrients and energy may be explained by differences in chemical composition, origin, and the processing of these feed ingredients (Table 2).

The test ingredients were efficiently utilized by mud crab, S. paramamosain as indicated by the high ADMD values (82.46\% to $89.20 \%$. Akiyama et al. (1989) reported in Penaeus vannamei that purified feedstuffs were efficiently digested compared with practical feedstuffs, which ranged from $21.4 \%$ to $91.4 \%$ The other result in P. setiferus showed that ADMD tended to decrease as dietary ash content of ingredients increased (Reigh et al., 1990). Soy bean meal protein is considered to be highly digestible to many crustacean species (Catacutan, 1997; Mu et al., 2000). In this study, the ADMD and ACPD of corn gluten were lower than for soy bean meal and similar results have been found for Penaeus setiferus (Brunson et al., 1997). However, the opposite was observed in crayfish, Procambarus clarkii (Reigh et al., 1990) and mud crab, S. serrata (Catacutan et al., 2003).

We therefore suggest that fish, head shrimp, and squid meal are suitable protein sources for mud crabs. Other ingredients, especially of soy bean meal, also appeared to be good dietary protein sources for mud crabs. It is therefore suggested that shrimp head meal and corn gluten meal are suitable dietary lipid sources for mud crabs (Table 3 ).

Fish meal is one of the most expensive and sought after ingredients for aquaculture diets and has become the most critical ingredient in aquafeed production. Increasing cost and demand of fish meal have encouraged feed manufacturers to search for cheaper alternative protein source such as plant protein. Fish nutritionists have tried to use less expensive plant protein to partially or totally replace fish meal. However, substitution of fish meal with other ingredients, especially of plant origin, is likely to compromise nutrient balance. Because of the increasing cost of fish meal and doubts concerning its long-term availability, much research has been carried out to find an alternative protein source.

Tuan et al. (2006) found that soy bean meal gave the highest ADMD $(P<0.05)$ for juvenile mud crabs (S. serrata, Forskal 1775). In another study (Catacutan et al., 2003) showed that soy bean gave lower ADMD than corn meal for juvenile mud crabs (S. serrata). Moreover, protein digestibility for shrimp meal was not significantly different from fish meal (Pe"0.05); nevertheless, it was lower than that of soybean meal. Findings such as these indicate that plantbased nutrient sources can be exploited to substitute fishmeal in formulated diets for mud crabs. In particular, the current findings suggest that soybean meal may be a useful component for formulating diets for $\mathrm{S}$. paramamosain.

Based on its digestibility values, it is proposed that soy bean meal is a suitable ingredient to substitute for fish meal in 
formulated diets for mud crabs. However, further research is needed to asses its performance in term of growth and survival of cultured mud crab.

\section{ACKNOWLEDGEMENTS}

Financial assistance was provided through ACIAR project no. FIS/ 2000/06 'Assessing the potential for low cost formulated diets for mud crab aquaculture in Australia, Indonesia and Vietnam'.

\section{REFERENCES}

Association of Official Analytical Chemists (AOAC). 1990. Official methods of analysis, $15^{\text {th }}$ edn. K. Helrich (Ed). AOAC, Arlington, USA.

Akiyama, D.M., S.R. Coelho, A. Lawrence, and E.H. Robinson. 1989. Apparent digestibility of feedstuff by marine shrimp, Penaeus vannamei Boone. Nippon Suisan Gakkaishi, 55: 91-98.

Brunson, J.F., R. Romaire, and R.C. Reigh. 1997. Apparent digestibility of selected ingredients in diets for white shrimp, Penaeus setiferus L. Aquac. Nutr., 3: 916.

Catacutan, M. 1997. Protein and dry matter digestibility of feedstuffs in complete diets for Penaeus monodon. In Zhou, Y., H. Zhou, C. Yao, Y. Lu F. Hu and F. Din. (Eds.), Proceeding of the fourth Asian Fisheries Forum. Asian Fisheries Society, China Ocean Press, p. 490-494.

Catacutan, M.R., P.S. Eusebio, and S. Teshima. Apparent digestibility of selected feedstuffs by mud crab, Scylla serrata. Aquaculture, 216: 253-261.

Cho, C.Y., S.J. Slinger, and M.S. Bayley. 1982. Bioenergetics of salmonid fishes: energy intake, expenditure and productivity. Comp. Biochem. Physiol., 73B: 25-41.

Fenucci, J., A.C. Fenucci, A. Lawrence, and Z. Zein- Eldin. 1982. The assimilation of protein and carbohydrate from prepared diets by shrimp Penaeus stylirostris. J. World Maric. Soc., 13: 134-145.

Forster, I. 1999. A note on the method of calculating digestibility coefficients of nutrients provided by single ingredients to feeds of aquatic animals. Aquacult. Nutr., 5: 143-145.

Furukawa, A. and H. Tsukahara. 1966. On the acid digestion method for determination of chromic oxides as an index substance in the study of digestibility of fish feed. Bulletin of Japanese Society of Fisheries, 32: 502-506.

Halver, J.E. and R.W. Hardy. 2002. Fish nutrition. Third edition. Academic Press New York, $824 \mathrm{pp}$.

Lee, G.P. and A. Lawrence. 1997. Digestibility. In L. D'Abramo, D. Conklin, D. Akiyama (Eds.), Crustacean nutrition advances in world aquaculture, vol VI. World Aquaculture Society, Baton Rouge, LA, USA, p. 194-260.

Mu, Y., T. Lam, J. Guo, and K. Shim. 2000. Protein digestibility and amino acid availability of several protein sources for juvenile Chinese hairy crab, Eriocheir sinensis $\mathrm{H}$ Milne- Edwards (Decapoda, Grapsidae). Aquac. Res., 31: 757-765.

Reigh, R.C., S. Braden, and R.J. Craig. 1990. Apparent digestibility coefficients for common feedstuffs in formulation diets for swamp crayfish, Procambarus clarkii. Aquaculture, 84: 321-334.

Steel, R.G.B. and J.H. Torrie. 1960. Principle and Procedures of Statistics. McGraw- Hill. New York, $481 \mathrm{pp}$.

Tuan, V.A., A. Andersen, J.L.Van, C. Shelley, and G. Allan. 2006. Apparent digestibility of some nutrient sources by juvenile mud crab, Scylla serrata (Forskal 1775). Aquaculture Res., 37: 359-365. 